\title{
Effects of Formaldehyde on Cardiac Function
}

\author{
Takayuki TANI and Yoshiya HORIGUCHI \\ Kanagawa Prefectural Public Health Laboratory, 52-2 Nakao-cho. Asahi-ku. \\ Yokohama 241. Japan
}

Accepted December 2.2.1989

\begin{abstract}
This investigation examined the effect of formaldehyde ( $\mathrm{HCHO}$ ) on cardiac function in in vitro cardiac preparations and in situ hearts of guinea pigs and rabbits. Though $\mathrm{HCHO}(0.2-4 \mathrm{mg} / \mathrm{kg}$, i.v.) produced noticeable bradycardiac and negative inotropic responses in anesthetized guinea pigs and rabbits, the responses to $\mathrm{HCHO}$ were far less in isolated guinea pig auricles and perfused hearts (Langendorff's preparations). The inhibitory responses to $\mathrm{HCHO}$ in the isolated auricles and perfused hearts were obtained at concentrations 200-400 times and 4-8 times higher than the blood concentrations attained in anesthetized animals. respectively. The responses in the isolated preparations were not significantly affected by propranolol. The bradycardiac response to the intravenously administered $\mathrm{HCHO}$ in anesthetized animals was not significantly affected by atropine or vagotomy, but was markedly attenuated by propranolol, reserpine or surgical denervation of the heart. These results indicate that the direct action of $\mathrm{HCHO}$ on the heart plays only a small role in the negative chronotropic response to $\mathrm{HCHO}$ in anesthetized animals. Furthermore, the negative chronotropic effect of $\mathrm{HCHO}$ in animals seems to be caused mainly by the inhibition of sympathetic nervous activity through the central nervous system.
\end{abstract}

Formaldehyde $(\mathrm{HCHO})$ is a highly reactive chemical and has various effects on living organisms such as sterilization, irritation of the eyes, skin and respiratory tract, and mutagenic and carcinogenic actions $(1-20)$. Furthermore, intravenously administered $\mathrm{HCHO}$ has been reported to produce transient reductions in heart rate, blood pressure and respiratory depression in anesthetized animals such as guinea pigs, rabbits and dogs $(21-24)$. We have previously reported that the hypotension induced by $\mathrm{HCHO}$ results from a combination of direct relaxation of vascular smooth muscles and inhibition of the sympathetic nervous system, and the direct vasodilator action plays a larger role in the hypotension than the sympathetic inhibition $(22,25)$. There are several reports describing the effects of $\mathrm{HCHO}$ on cardiac function, but the mechanism of the decrease in heart rate induced by intravenously administered $\mathrm{HCHO}$ in anesthetized animals have not been thoroughly studied so far (26-29). In this investigation. we studied the mechanism of the $\mathrm{HCHO}$ effect on cardiac function.

\section{Materials and Methods}

Animals: Male Japanese albino rabbits weighing $2.4-3.4 \mathrm{~kg}$ and Hartley strain guinea pigs weighing 400-600 g (Shizuoka Laboratory Animal Center) were used for the present study. The animals were maintained in a room at $22 \pm 2{ }^{\circ} \mathrm{C}$ and were given laboratory chow (CR-1 or CG-3. Clea Japan Inc.) and tap water ad libitum.

Measurement of heart rate and blood pressure in anesthetized animals: Twenty-six rabbits and thirty-two guinea pigs were anesthetized with urethane $(1.0-1.2 \mathrm{~g} / \mathrm{kg}$, i.p.), and the following parameters were recorded simultaneously with a multipurpose polygraph (Nihon Kohden, RM-6000): 1) blood pressure (BP) through an arterial catheter inserted into the left femoral artery, 2) heart rate (HR) through a cardiotachometer (Nihon Kohden. AT-600G) triggered by ECG, and 3) respiratory movement (RM) of the thorax wall by means of a thoracic pickup (Nihon Kohden, 
TR-601T). Drugs were given through a cannula inserted into the right femoral vein in rabbits and the right jugular vein in guinea pigs. Sodium heparin (300-500 U/kg, i.v.) was used as an anticoagulant.

Surgical denervation of the heart and vagotomy: Five rabbits were anesthetized with urethane (1.0-1.2 g/kg. i.p.). Each rabbit was placed on its back on a table, and its chest was opened under artificial respiration. Nerves to the heart running in the connective tissue around the aorta, vena cava superior, pulmonary aorta and vein were cut according to the method of surgical denervation of the heart (30).

Vagotomy was carried out by cutting both vagus nerves at the neck.

Isolated guinea pig auricles: Four guinea pigs were killed by exsanguination under light ether anesthesia. The chests were opened, and the hearts were removed as quickly as possible, placed in a dissection bath filled with Ringer-Locke solution at room temperature and the atria were excised. The Ringer-Locke solution contained: $154 \mathrm{mM}$ $\mathrm{NaCl}, 5.6 \mathrm{mM} \mathrm{KCl}, 1.1 \mathrm{mM} \mathrm{CaCl} 2,6.0 \mathrm{mM}$ $\mathrm{NaHCO}_{3}, 5.6 \mathrm{mM}$ glucose. The preparation was mounted in a bath containing RingerLocke solution aerated with $100 \% \mathrm{O}_{2}$. The bath temperature was maintained at $30^{\circ} \mathrm{C}$. One end of the auricles was fixed to a pin in the bath bottom by thread and the other connected to a force-displacement transducer (Nihon Kohden. SB-1T). The contractile force and the beating rate were registered simultaneously on a recorder (Hitachi, 056). When the contractile force and beating rate became stable after the equilibration period of 30 to $60 \mathrm{~min}$. drugs were introduced into the bath solution in a cumulative fashion, and the effects of the drugs were recorded.

Isolated perfused guinea pig heart (Langendorff's preparation): Fourteen guinea pigs were killed by exsanguination under light ether anesthesia, and the hearts were removed as guickly as possible. Then isolated perfused guinea pig heart preparations were prepared according to the usual method (31). The preparation was retrogradely perfused with Krebs-Henseleit solution having the following composition: $118 \mathrm{mM} \mathrm{NaCl}, 4.7 \mathrm{mM} \mathrm{KCl}, 2.5$ $\mathrm{mM} \mathrm{CaCl}_{2}, 1.2 \mathrm{mM} \mathrm{MgSO}_{4} \cdot 7 \mathrm{H}_{2} \mathrm{O}, 1.2 \mathrm{mM}$
$\mathrm{KH}_{2} \mathrm{PO}_{4}, 25.0 \mathrm{mM} \quad \mathrm{NaHCO}_{3}, 11.1 \mathrm{mM}$ glucose. The perfusate was oxygenated by a mixed gas of $95 \% \mathrm{O}_{2}$ and $5 \% \mathrm{CO}_{2}$, and its temperature was maintained at $37 \pm 0.5^{\circ} \mathrm{C}$. The perfusion was carried out at a constant flow rate of $1.5-2.0 \mathrm{ml} / \mathrm{min}$ using a pump (Mitsumi Science, SJ-1210). The contractile force was recorded with the force-displacement transducer connected to the apex of the heart through a thread. Heart rate was counted by the signal of the contractile force. The contractile force and heart rate were registered simultaneously on the recorder. When the contractile force and heart rate became stable in 30 to $60 \mathrm{~min}$ after setting up the preparation, the perfusion fluid was changed to fluid containing drugs, and then the effects of the drugs on the preparation were recorded.

Drugs: Because commercially available formalin contains methanol as a stabilizer, we prepared methanol-free formaldehyde by distilling hexamethylentetramine (Wako Pure Chemical) with sulfuric acid. The concentration of formaldehyde $(\mathrm{HCHO})$ in the distillate was determined by iodimetry (32). Other drugs used were urethane (Sigma Chemical). anesthetic ether (Showa Ether), sodium heparin (Novo). DL-propranolol hydrochloride (Sigma Chemicals), reserpine (Apoplon ${ }^{3}$ Inj.. Daiichi Seiyaku), atropine sulfate (Sigma Chemicals).

Analysis of data: Statistical significance of data was analyzed by Student's $t$-test, and data are presented as the mean \pm S.E.

\section{Results}

Responses to intravenous injection of $\mathrm{HCHO}$ in anesthetized guinea pigs and rabbits

$\mathrm{HCHO}(0.2-0.4 \mathrm{mg} / \mathrm{kg})$, when intravenously given, produced immediately noticeable reductions in heart rate, blood pressure and respiratory movement in the chest in anesthetized guinea pigs. $\mathrm{HCHO}(2-4 \mathrm{mg} /$ $\mathrm{kg}$ ) produced similar effects in rabbits, although the responses to $\mathrm{HCHO}$ were about ten times smaller in rabbits than in guinea pigs. when compared on the basis of dose (Fig. 1)

Effects of $\mathrm{HCHO}$ on isolated guinea pig auricles

Assuming that the total blood volume is $8 \%$ of the whole body weight, the theoretical con- 


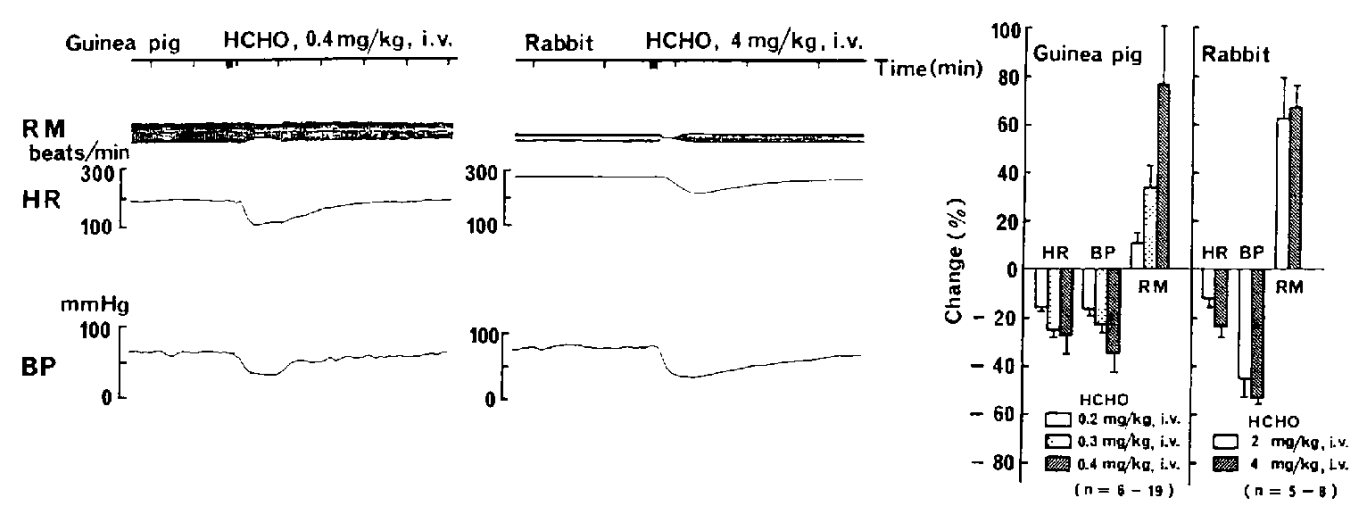

Fig. 1. Responses of the heart rate (HR), blood pressure (BP) and respiratory movement (RM) to i.v. injection of $\mathrm{HCHO}$ in anesthetized guinea pigs and rabbits. Control values in guinea pigs $(0.2 \mathrm{mg} / \mathrm{kg}$ $\mathrm{HCHO}$. i.v: $\mathrm{HR}=233 \pm 9 . \mathrm{BP}=43 \pm 4: 0.3 \mathrm{mg} / \mathrm{kg} \mathrm{HCHO}$, i.v.: $\mathrm{HR}=237 \pm 9 . \mathrm{BP}=47 \pm 4: 0.4 \mathrm{mg} / \mathrm{kg} \mathrm{HCHO}$. i.v.: $H R=234 \pm 7, B P=53 \pm 4)(n=6-19)$. Control values in rabbits $(2 \mathrm{mg} / \mathrm{kg} \mathrm{HCHO}$, i.v: $: H R=258 \pm 8$. $\mathrm{BP}=76 \pm 5 ; 4 \mathrm{mg} / \mathrm{kg} \mathrm{HCHO}$, i.v.: $\mathrm{HR}=265 \pm 11 . \mathrm{BP}=80 \pm 3)(\mathrm{n}=5-8)$. Each value represents the mean \pm S.E. HR: beats/min, BP: $\mathrm{mmHg}$.
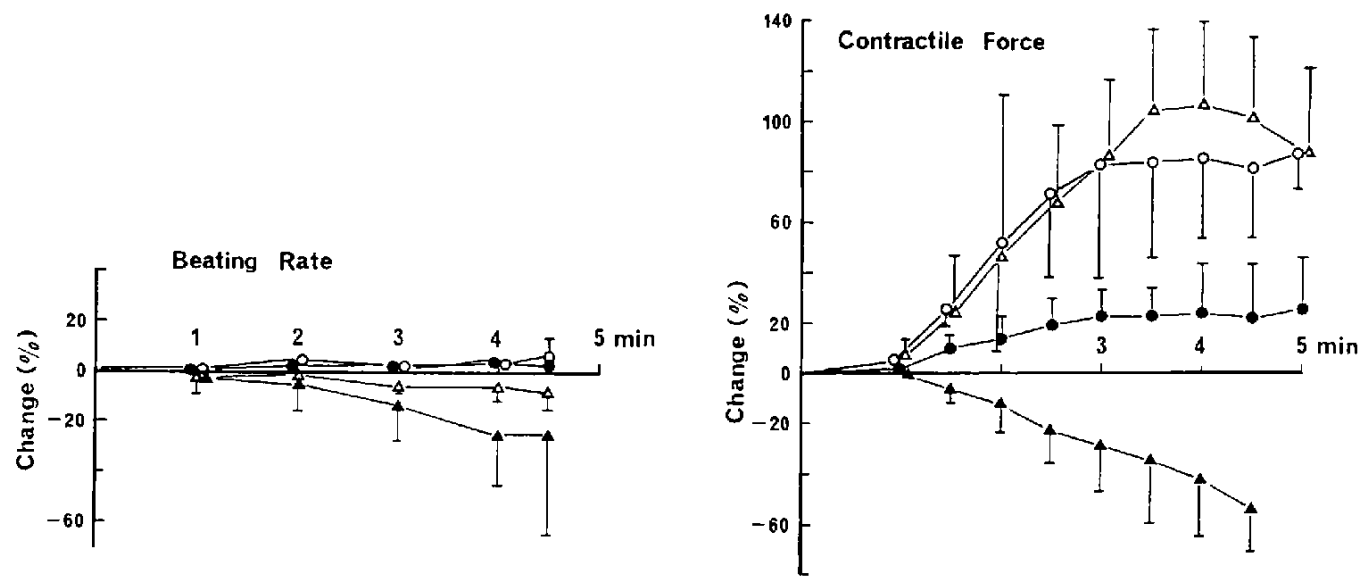

Fig. 2. Effects of $\mathrm{HCHO}$ on the beating rate and contractile force in isolated guinea pig auricles. RingerLocke solution. $30^{\circ} \mathrm{C}, \mathrm{O}_{2}$. $\mathrm{CF}: 0.46 \pm 0.07): \mathrm{O}-\mathrm{OCHO} .3 .3 \times 10^{-3} \mathrm{M}\left(10^{-4} \mathrm{~g} / \mathrm{ml}\right.$ ), control values (BR: $107 \pm 15, \mathrm{CF}: 0.43 \pm$ 0.02): $\triangle-\triangle:$ HCHO. $6.6 \times 10^{-3} \mathrm{M}\left(2 \times 10^{-4} \mathrm{~g} / \mathrm{ml}\right)$. control values (BR: $\left.114 \pm 7 . \mathrm{CF}: 0.46 \pm 0.08\right)$; $\mathbf{A}-\mathbf{A}: \mathrm{HCHO}, 3.3 \times 10^{-2} \mathrm{M}\left(10^{-3} \mathrm{~g} / \mathrm{ml}\right)$, control values (BR: $\left.105 \pm 1 . \mathrm{CF}: 0.47 \pm 0.09\right)$. Each value represents the mean \pm S.E. $(n=4)$. BR: beating rate (beats/min). CF: contractile force $(g)$.

centration of $\mathrm{HCHO}$ in the blood, when $\mathrm{HCHO}$ was intranvenously administered at the doses of $0.2-0.4 \mathrm{mg} / \mathrm{kg}$ in guinea pigs is calculated to be $2.5-5 \times 10^{-6} \mathrm{~g} / \mathrm{ml}$. In the isolated auricle preparation. $\mathrm{HCHO}$ even at the concentration of $10^{-4} \mathrm{~g} / \mathrm{ml}$ did not affect the beating rate (Fig. 2). Increasing the concentration up to $10^{-3} \mathrm{~g} / \mathrm{ml}$ produced a decrease in beating rate (Fig. 2). However, the decrease did not reach statistical significance. The contractile force was clearly increased by $\mathrm{HCHO}$ in a concentration range of $2 \times 10^{-5}$ to $2 \times 10^{-4} \mathrm{~g} / \mathrm{ml}$. However, when the concentration of $\mathrm{HCHO}$ was increased to $10^{-3} \mathrm{~g} / \mathrm{ml}$, it produced a negative inotropic effect.

Effects of $\mathrm{HCHO}$ on isolated guinea pig perfused heart (Langendorff's preparation)

As shown in Fig. 3, in the isolated perfused 

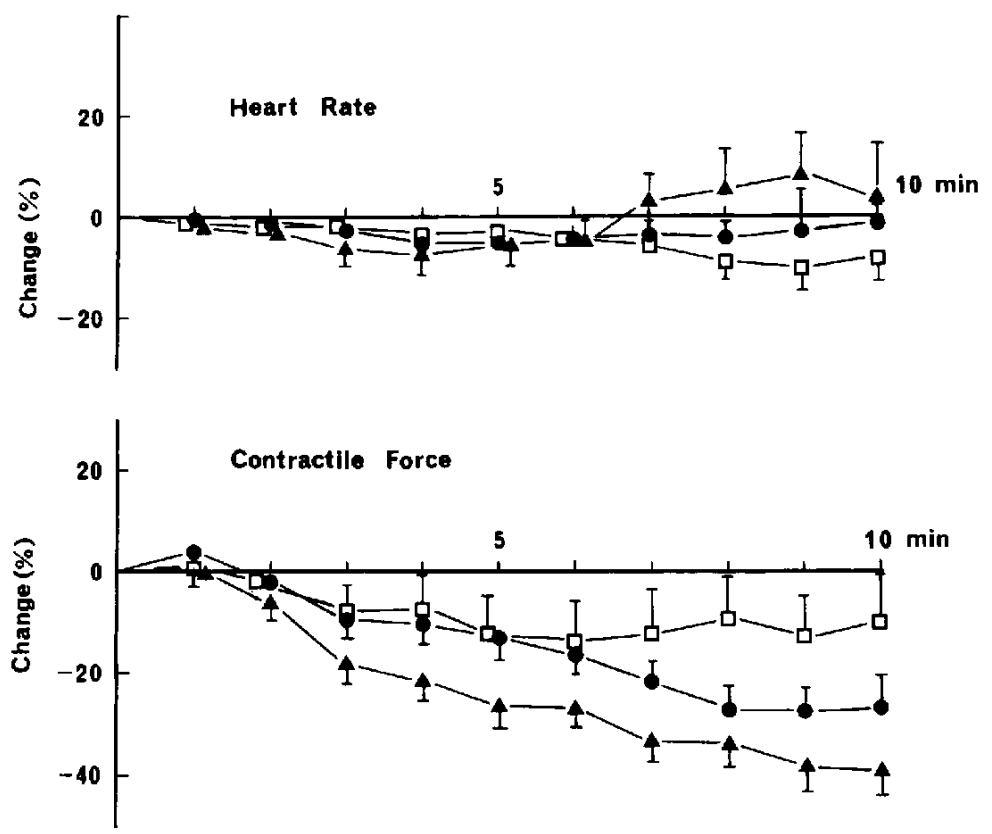

Fig. 3. Effects of $\mathrm{HCHO}$ on the heart rate and contractile force in isolated guinea pig perfused hearts (Langendorff's preparations). Krebs-Henseleit solution, $37^{\circ} \mathrm{C}, 95 \% \mathrm{O}_{2}+5 \% \mathrm{CO}_{2}$. $\square-\square$ : $\mathrm{HCHO}$. $3.3 \times 10^{-4} \mathrm{M}\left(10^{-5} \mathrm{~g} / \mathrm{ml}\right)$, control values (HR: $88 \pm 16$, CF: $\left.2.1 \pm 0.8\right): 0-\mathrm{HCHO}, 6.6 \times 10^{-4} \mathrm{M}$ $\left(2 \times 10^{-5} \mathrm{~g} / \mathrm{ml}\right)$, control values (HR: $\left.91 \pm 9, \mathrm{CF}: 2.2 \pm 0.5\right) ; \mathbf{A}-\mathbf{A}$ : HCHO, $1.3 \times 10^{-3} \mathrm{M}\left(4 \times 10^{-6} \mathrm{~g} / \mathrm{ml}\right)$, control values (HR: $93 \pm 8, C F: 2.1 \pm 0.4)$. Each value represents the mean $\pm S . E .(n=4-10)$. HR: heart rate (beats/min), CF: contractile force $(g)$.

heart preparation, $\mathrm{HCHO}\left(1-4 \times 10^{-5} \mathrm{~g} / \mathrm{ml}\right)$ produced inconsistent changes in the heart rate. which was not significantly different from the control values, while HCHO significantly suppressed the contractile force at concentrations higher than $10^{-5} \mathrm{~g} / \mathrm{ml}$. The concentration of $2 \times 10^{-5} \mathrm{~g} / \mathrm{ml}$ was four to eight times as high as the theoretical blood concentration of $\mathrm{HCHO}\left(2.5-5 \times 10^{-6} \mathrm{~g} / \mathrm{ml}\right)$ calculated in guinea pigs that intravenously received $\mathrm{HCHO}$ at the doses of $0.2-0.4 \mathrm{mg} / \mathrm{kg}$. Propranolol $\left(1.9 \times 10^{-5} \mathrm{M}\right)$ did not significantly affect the decreased contractile force and the altered heart rate by $\mathrm{HCHO}\left(2 \times 10^{-5}\right.$, $4 \times 10^{-5} \mathrm{~g} / \mathrm{ml}$ ) (Fig. 4). Propranolol hardly affected the control value of heart rate, but depressed the contractile force by about $15 \%$ in Langendorff's preparations.

Effects of autonomic blockers and surgical denervation of the heart on responses to $\mathrm{HCHO}$ in anesthetized animals

(1) Atropine and vagotomy: Though the the bradycardiac response to $\mathrm{HCHO}(4 \mathrm{mg} /$ $\mathrm{kg}$, i.v.) was slightly inhibited by atropine (2 $\mathrm{mg} / \mathrm{kg}, \mathrm{i} . \mathrm{v}$.) and by a combination of atropine and vagotomy, the difference in the response before and after the vagolytic procedure of atropine and vagotomy was statistically insignificant in five rabbits. Similarly, the procedure did not significantly affect the fall of blood pressure induced by intravenously administered $\mathrm{HCHO}$. Guinea pigs showed results similar to those in rabbits (Table 1 ).

(2) Propranolol: The bradycardiac response to $\mathrm{HCHO}$ (4 mg/kg, i.v.) was mostly abolished by propranolol ( $2 \mathrm{mg} / \mathrm{kg}$. i.v.) in four rabbits. Though the fall of blood pressure induced by the intravenously administered $\mathrm{HCHO}$ tended to be decreased by propranolol, it was not entirely abolished (Fig. 5. Table 1). Guinea pigs showed results similar to those obtained in rabbits (Table 1). Propranolol had little effect on the resting level of blood pressure, but decreased the heart rate by about $50 \%$ in rabbits and guinea pigs.

(3) Reserpine: The decrease in the heart 

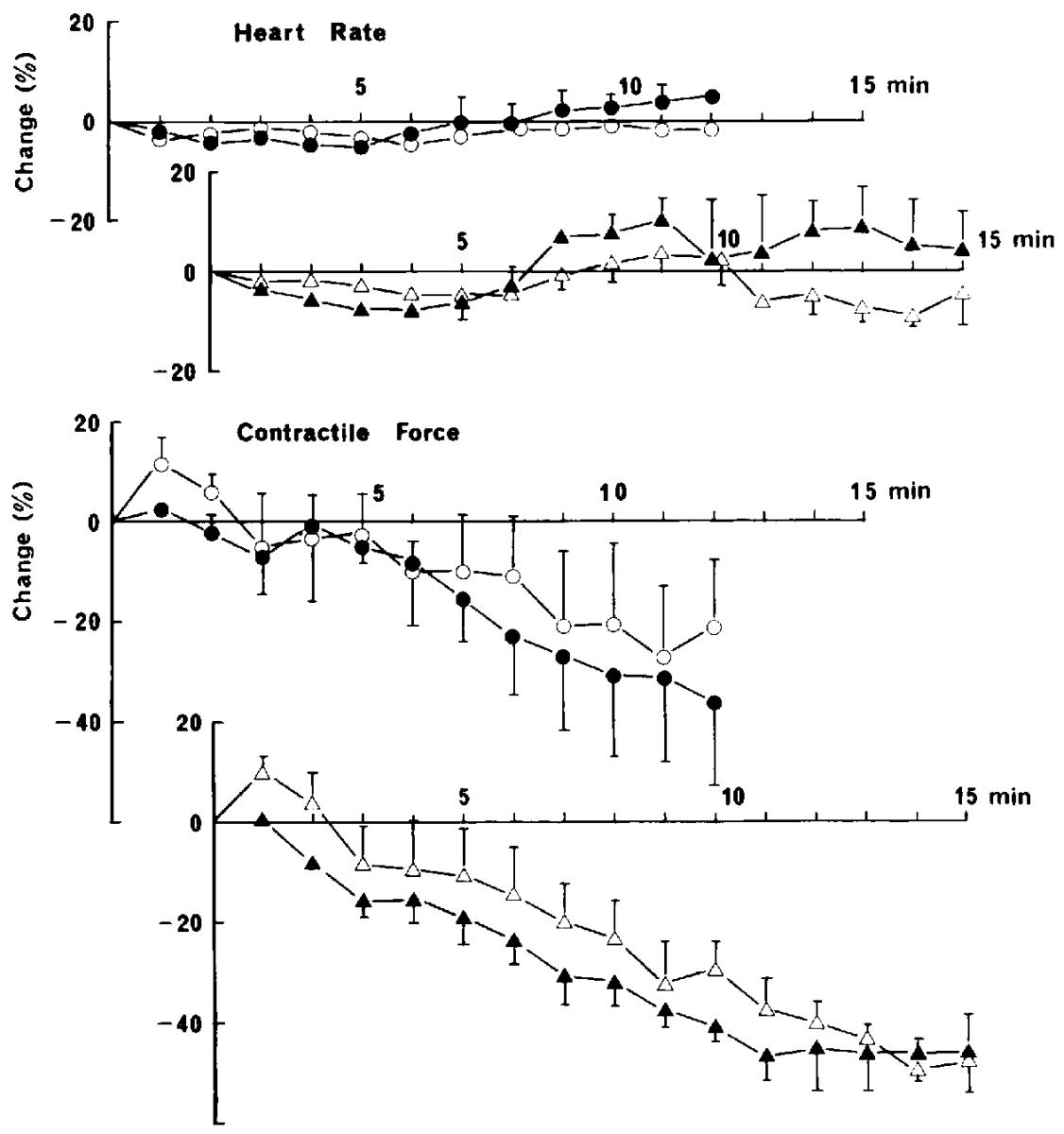

Fig. 4. Effects of propranolol on the heart rate and contractile force induced by $\mathrm{HCHO}$ in isolated guinea pig perfused hearts (Langendorff's preparations). Krebs-Henseleit solution, $37^{\circ} \mathrm{C}, 95 \% \mathrm{O}_{2}+5 \% \mathrm{CO}_{2}$. - $\mathrm{HCHO}, 6.6 \times 10^{-4} \mathrm{M}\left(2 \times 10^{-5} \mathrm{~g} / \mathrm{ml}\right)$, control values (HR: $\left.105 \pm 2, \mathrm{CF}: 2.0 \pm 0.4\right): \mathrm{O}-\mathrm{O}$ : Propranolol $\left(1.9 \times 10^{-5} \mathrm{M}\right)+\mathrm{HCHO}\left(6.6 \times 10^{-4} \mathrm{M}\right)$, control values (before propranolol, HR: $104 \pm 3, \mathrm{CF}$ : 2.1 \pm 0.1 : after propranolol. HR: $102 \pm 6 . \mathrm{CF}: 1.8 \pm 0.3) ; \Delta-\mathbf{A C H O}, 1.3 \times 10^{-3} \mathrm{M}\left(4 \times 10^{-5} \mathrm{~g} / \mathrm{ml}\right)$, control values (HR: $99 \pm 2, \mathrm{CF}: 2.1 \pm 0.5): \triangle \longrightarrow \triangle$ : Propranolol $\left(1.9 \times 10^{-6} \mathrm{M}\right)+\mathrm{HCHO}\left(1.3 \times 10^{-3} \mathrm{M}\right)$. control values (before propranolol, HR: $101 \pm 3, \mathrm{CF}: 2.0 \pm 0.4$; after propranolol, HR: $99 \pm 3, \mathrm{CF}: 1.7 \pm 0.3$ ). Each value represents the mean $\pm S$.E. $(n=4)$. HR: heart rate (beats $/ \mathrm{min})$. CF: contractile force $(g)$.

rate by $\mathrm{HCHO}$ (4 $\mathrm{mg} / \mathrm{kg}$, i.v.) was almost abolished by pretreatment ( $24 \mathrm{hr}$ before the experiment) with reserpine (5 $\mathrm{mg} / \mathrm{kg}$. s.c.) in four rabbits. Though the decreased blood pressure by intravenously administered $\mathrm{HCHO}$ was apparently inhibited by reserpine, it still remained (Fig. 6). Furthermore, the bradycardiac response to $\mathrm{HCHO}$ in four reserpinized guinea pigs was almost abolished, like that in rabbits (data not shown).

(4) Surgical denervation of the heart: The decrease in the heart rate by $\mathrm{HCHO}(4 \mathrm{mg} / \mathrm{kg}$. i.v.) was almost abolished by surgical denervation of the heart in five rabbits. On the other hand, although the fall of blood pressure induced by intravenously administered $\mathrm{HCHO}$ was significantly decreased by the surgical denervation of the heart, it still persisted (Fig. 7. Table 1).

\section{Discussion}

In this study, we investigated the mechanism of the bradycardia induced by intravenously administered $\mathrm{HCHO}$ in anesthe- 


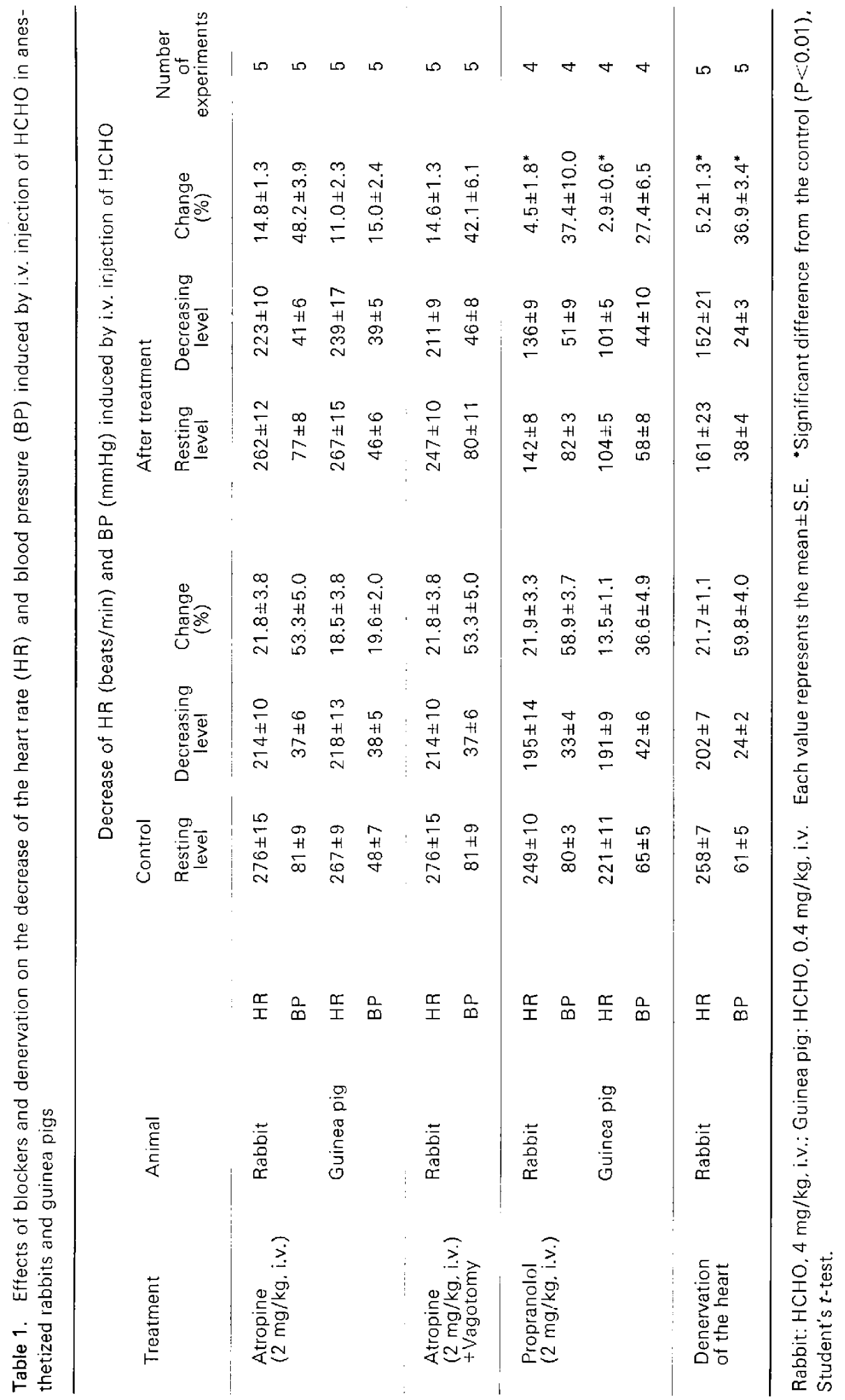




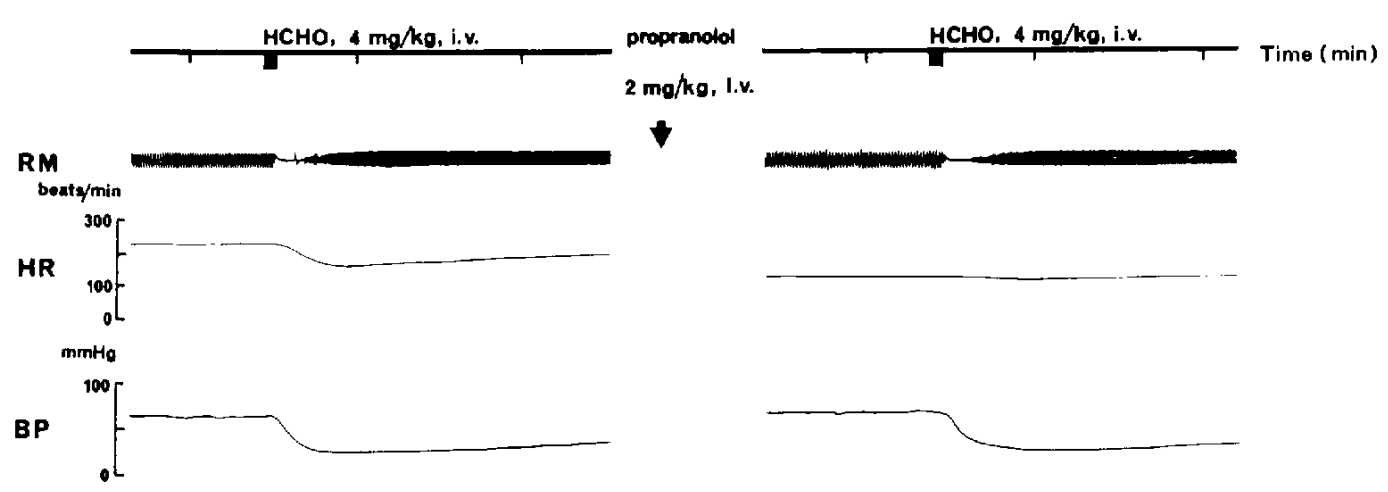

Fig. 5. Effects of propranolol on the heart rate (HR), blood pressure (BP) and respiratory movement (RM) induced by $\mathrm{HCHO}$ in an anesthetized rabbit.

HCHO, $4 \mathrm{mg} / \mathrm{kg}$, l.v.

T Time (min)

RM
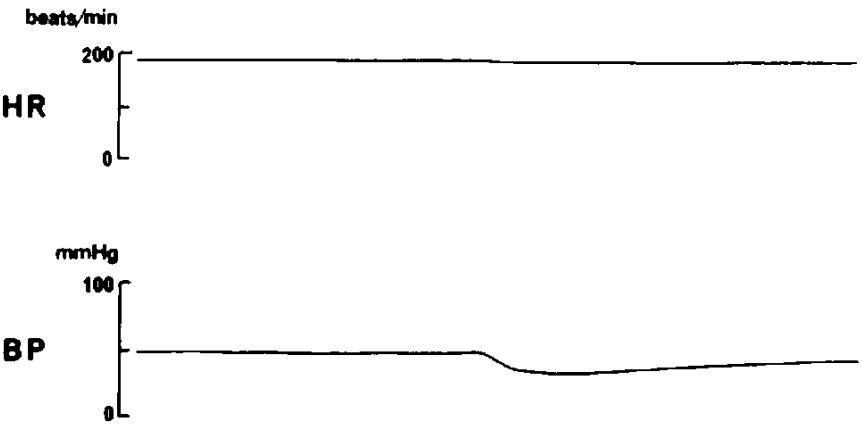

Fig. 6. Responses of the heart rate (HR), blood pressure (BP) and respiratory movement (RM) to i.v. injection of $\mathrm{HCHO}$ in a reserpinized rabbit. Reserpine. $5 \mathrm{mg} / \mathrm{kg}$, s.C., $24 \mathrm{hr}$ before the experiment.

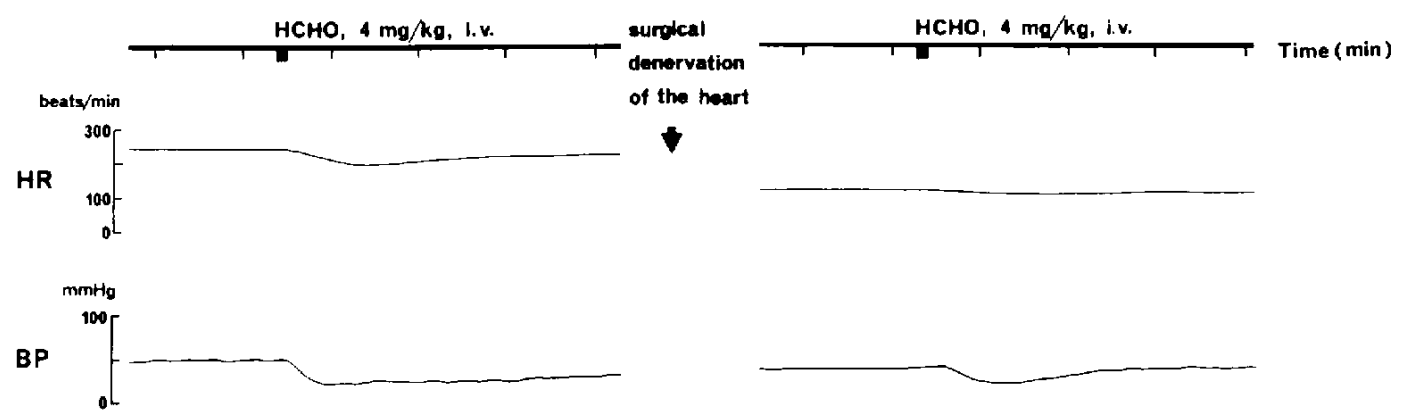

Fig. 7. Effects of surgical denervation of the heart on the heart rate (HR) and blood pressure (BP) induced by $\mathrm{HCHO}$ in an anesthetized rabbit. $\mathrm{HCHO}$ was injected in about 15-20 minutes after the denervation. 
tized guinea pigs and rabbits. A comparison of the bradycardiac response to $\mathrm{HCHO}$ in these animals revealed that guinea pigs were about ten times more sensitive to $\mathrm{HCHO}$ than rabbits. At the present time we can not explain this species difference in sensitivity to $\mathrm{HCHO}$. Because of the high sensitivity to $\mathrm{HCHO}$ in guinea pigs, we employed mainly guinea pigs for the experiments using isolated heart preparations. The concentration $\left(10^{-3} \mathrm{~g} / \mathrm{ml}\right)$ at which $\mathrm{HCHO}$ clearly depressed the beating rate in isolated auricles was 200 to 400 times higher than the theoretical blood concentration of $\mathrm{HCHO}\left(2.5-5 \times 10^{-6} \mathrm{~g} / \mathrm{ml}\right)$ calculated from the dose at which $\mathrm{HCHO}$ significantly decreased the heart rate in anesthetized guinea pigs. Moreover, in isolated auricle preparations, the contractile force was obviously suppressed by $\mathrm{HCHO}$ at the high concentrations $\left(10^{-3} \mathrm{~g} / \mathrm{ml}\right)$, but was increased by $\mathrm{HCHO}$ at the concentrations $(2 \times$ $10^{-5}-2 \times 10^{-4} \mathrm{~g} / \mathrm{ml}$ ) less than $10^{-3} \mathrm{~g} / \mathrm{ml}$. The cause of the increasing response in contractile force to $\mathrm{HCHO}$ was not examined. However, this increasing response is apparently not due to the release of endogenous catecholamines, because propranolol did not affect the inotropic response in the isolated auricles and in the perfused hearts (data not shown). Further investigation is necessary to clarify this point. The concentration $\left(2 \times 10^{-5} \mathrm{~g} / \mathrm{ml}\right)$ at which $\mathrm{HCHO}$ did not decrease the heart rate but suppressed the contractile force in isolated perfused hearts was four to eight times as high as the theoretical blood concentration of $\mathrm{HCHO}$ at which $\mathrm{HCHO}$ produced the bradycardiac effect in anesthetized guinea pigs. Moreover, propranolol had no significant effect on the suppression of the contractile force and the change of heart rate induced by $\mathrm{HCHO}(2 \times$ $10^{-5}, 4 \times 10^{-5} \mathrm{~g} / \mathrm{ml}$ ) in isolated perfused hearts. As mentioned above, although $\mathrm{HCHO}$ at low doses markedly inhibited the heart rate in anesthetized animals, $\mathrm{HCHO}$ at concentrations low enough correspond to the blood concentrations attainable in in vivo experiments did not inhibit cardiac function in isolated heart preparations. Only higher concentrations of $\mathrm{HCHO}$ produced the inhibitory response. Therefore, these results suggest that the bradycardiac response to $\mathrm{HCHO}$ seems unlikely to be due to its direct effect on the heart.

Pretreatment with atropine and surgical vagotomy had no significant effect on the negative chronotropic response to intravenously given $\mathrm{HCHO}$ in anesthetized animals. However, propranolol almost blocked this response. This finding indicates that the bradycardiac response to $\mathrm{HCHO}$ is due to a decrease in sympathetic nervous activities rather than due to increase in parasympathetic nervous activities.

The negative chronotropic response to $\mathrm{HCHO}$ was also blocked by reserpine. This fact further supports the idea that the decrease in the heart rate induced by $\mathrm{HCHO}$ results from the influence of $\mathrm{HCHO}$ on the sympathetic nervous system, that is, inhibiting transmitter release at the adrenergic nerve endings.

Interruption of tonic influence from the central nervous system by acute surgical denervation in cardiac sympathetic nerves did abolish the negative chronotropic response to $\mathrm{HCHO}$, suggesting that the possible site of interaction of $\mathrm{HCHO}$ with the sympathetic nerves may be located in the central nervous system, even if only partly.

Concerning the fall of blood pressure induced by $\mathrm{HCHO}$ in rabbits, pretreatment with propranolol or reserpine attenuated it, but did not entirely abolish it. As described in the previous paper $(22,25)$, the fall of blood pressure induced by intravenously administered $\mathrm{HCHO}$ is caused by a combination of the direct relaxation of vascular smooth muscle and the inhibition of the sympathetic nervous system. The fall in blood pressure observed in this experiment appears to be produced mainly by the relaxation of vascular smooth muscle.

These results suggest that the direct action of $\mathrm{HCHO}$ on the heart was negligible for inducing the negative chronotropic response in anesthetized animals. Furthermore, the negative chronotropic effect of $\mathrm{HCHO}$ in animals seems to be caused mainly by the inhibition of sympathetic nervous activity through the central nervous system.

\section{References}

1 National Center for Toxicologic Research NCTR: 
Report on the consensus workshop on formaldehyde. Environ. Health Perspect. 58, 328-381 (1984)

2 Skog, E.: A toxicological investigation of lower aliphatic aldehydes. I. Toxicity of formaldehyde, acetaldehyde, propionaldehyde and butyraldehyde: as well as of acrolein and crotonaldehyde. Acta Pharmacol. 6, 299-318 (1950)

3 Skog, E: Anesthetic and haemolytic action of lower aliphatic aldehydes and their effect on respiration and blood pressure. Acta Pharmacol. Toxicol, 8, 275-289 (1952)

4 Amdur, M.O.: The response of guinea pigs to inhalation of formaldehyde and formic acid alone and with a sodium chloride aerosol. Int. J. Air Pollut. 3, 201-220 (1960)

5 Egle, J.L., Jr. and Richmond, V.: Retention of inhaled formaldehyde, propionaldehyde, and acrolein in the dog. Arch. Environ. Health 25, 119-124 (1972)

6 Kulle, T.J. and Cooper, G.P.: Effects of formaldehyde and ozone on the trigeminal nasal sensory system. Arch. Environ. Health 30, 237$243(1975)$

7 Kane, L.E. and Alarie, Y.: Sensory irritation to formaldehyde and acrolein during single and repeated exposures in mice. Am. Ind. Hyg. Assoc. J. 38, 509-522 (1977)

8 Chang, J.C.F., Steinhagen, W.H. and Barrow, C.S.: Effect of single or repeated formaldehyde exposure on minute volume of B6C $3 F 1$ mice and F-344 rats. Toxicol. Appl. Pharmacol. 61, 451459 (1981)

9 Jaeger, R.J. and Gearhart, J.M.: Respiratory and metabolic response of rats and mice to formalin vapor. Toxicology 25, 299-309 (1982)

10 Tani, T., Kogi, K. and Horiguchi, Y.: Inhibitory effects of formaldehyde inhalation on the cardiovascular and respiratory systems in unanesthetized rabbits. Japan. J. Pharmacol. 40, $551-559$ (1986)

11 Sugai, H.: Clinical and experimental studies of ocular impairment caused by exposure to formaldehyde. J. Ophthal. Japan 59, 628-658 (1955) (in Japanese)

12 Kawano, M.: The effect of orally administrated formaldehyde on the mouse retina-electron microscopic studies of the pigment epithelium. Folia Ophthal. Japon. 26, 529-541 (1975)

13 Uehara, M.: Follicular contact dermatitis due to formaldehyde. Dermatologica 156, 48-54 (1978)

14 Lee, H.K., Alarie, Y. and Karol, M.H.: Induction of formaldehyde sensitivity in guinea pigs. Toxicol. Appl. Pharmacal. 75, 147-155 (1984)
15 Auerbach, C., Moutshen-Dahmen, M. and Moutschen, J.: Genetic and cytogenetical effects of formaldehyde and related compounds. Mutat. Res. 39, 317-362 (1977)

16 Swenberg, J.A., Kerns, W.D., Mitchell, R.I., Gralla, E.J. and Pavkov, K.L.: Induction of squamous cell carcinomas of the rat nasal cavity by inhalation exposure to formaldehyde vapor. Cancer Res. 40, 3398-3402 (1980)

17 Kerns, W.D., Pavkov, K.L., Donofrio, D.J., Gralla, E.J. and Swenberg, J.A.: Carcinogenicity of formaldehyde in rats and mice after long-term inhalation exposure. Cancer Res. 43, 4382-4392 (1983)

18 Morgan, K.T., Jiang, X.-Z., Starr, T.B. and Kerns, W.D.: More precise localization of nasal tumors associated with chronic exposure of F-344 rats to formaldehyde gas. Toxicol. Appl. Pharmacol. 82, 264-271 (1986)

19 Igari, T.: Studies on mechanism of paraformaldehyde-induced hypothermia. Shikwa Gakuho 82, 283-301 (1982) (Abs. in English)

20 Beckner, J.S., Hudgins, P.M. and Egle, J.L., Jr.: Effects of acetaldehyde, propionaldehyde, formaldehyde and acrolein on contractility, ${ }^{14} \mathrm{C}$ norepinephrine and ${ }^{45} \mathrm{Ca}$ binding in isolated smooth muscle. Res. Commun. Chem. Pathol. Pharmacol. 9, 471-488 (1974)

21 Tani, T., Satoh, S., Tsuchiya, H., Horiguchi, Y., Wada, $Y$. and Takahashi, T.: Hygienic study on packaging and vessel made of synthetic resin (IV). Potentiation of urea on the depressor action of formaldehyde in dog blood pressure. $J$. Food Hyg. Soc. Japan 17, 236-240 (1976)

22 Tani, T., Satoh, S. and Horiguchi, Y.: The vasodilator action of formaldehyde in dogs. Toxicol. Appl. Pharmacol. 43, 493-499 (1978)

23 Akabane, J., Kohei, H., Matsumura, R., Ouchi, T., Yamamura, S., Masamura, E. and Nakanishi, S.: Pharmacological studies on formaldehyde. Med. J. Shinshu Univ. 13, 1-7 (1968)

24 Wingard, C., Hitchcock, P. and Teague, R.S.: A survey of aldehydes with respect to their action on the blood pressure. Arch. Int. Pharmacodyn. Ther. 102, 65-84 (1955)

25 Tani, T.: Relaxation of vascular smooth muscle induced by formaldehyde. Folia Pharmacol. Japon. 77, 221-230 (1981) (Abs. in English)

26 James, T.N. and Bear, E.S.: Cardiac effects of some simple aliphatic aldehydes. J. Pharmacol. Exp. Ther. 163, 300-308 (1968)

27 Fozzard, H.A. and Dominguez, G.: Effect of formaldehyde and glutaraldehyde on electrical properties of cardiac Purkinje fibers. J. Gen. Physiol. 53, 530-540 (1969) 
28 Krames, B. and Page, E.: Effects of electronmicroscopic fixatives on cell membranes of the perfused rat heart. Biochim. Biophys. Acta 150, 24-31 (1968)

29 Egle, J.L., Jr. and Hudgins, P.M.: Dose-dependent sympathomimetic and cardioinhibitory effects of acrolein and formaldehyde in the anesthetized rat. Toxicol. Appl. Pharmacol. 28, 358-366 (1974)

30 Akera, T.: The function of cardiosympathetic nerves. In Experimental Methods for Cardiovascular Pharmacology. Edited by Tanabe. T.
Yasuda, H., Taira, N. and Kanno, M.. p. 209-211 Maruzen Company. Tokyo (1981) (in Japanese)

31 Sakai, K. and Shiraki, Y.: A device for recording left ventricular contraction and electrocardiogram in nonworking isolated perfused rat heart. Japan. J. Pharmacol. 28, 223-229 (1978)

32 Wada, $Y .$, Watanabe, S. and Takahashi, T.: Hygienic study on packaging and vessel made of synthetic resin (II). Determination method of formaldehyde by liquid column chromatography with thermal detector. J. Food Hyg. Soc. Japan 15, 434-439 (1974) (Abs. in English) 